\title{
Appropriate behaviour in the forests of Wienerwald Biosphere Reserve
}

\author{
Günter Köck \& Harald Brenner
}

Keywords: Wienerwald Biosphere Reserve, forest utilization, participatory management, visitor guidance

\section{Abstract}

The unique location of Wienerwald Biosphere Reserve on the edge of the large city of Vienna provides easy access for the urban population and makes for complex challenges, such as high visitor pressure and habitat fragmentation. The Wienerwald area is a popular local recreation space, where the population of the city and its environs pursues a variety of leisure activities, such as mountain biking, horse riding, jogging and climbing. Various decrees and bans regulate the pursuit of these sports as well as other activities like forestry in the three zones (core zone, buffer zone, development zone) of the biosphere reserve (BR). This leads almost automatically to conflicts between individual user groups, as well as between visitors and land owners, and between all of them and the protected area management. This is why the Wienerwald BR management has engaged in an exemplary participation process with land owners, interest groups and major actors in the region to create an information booklet. It explains the raison d'ètre and the aims of the BR, the characteristics of the three zones and the related bans, decrees and permitted forms of use. The text presents the necessary rules of behaviour for all involved in easily comprehensible form to promote harmonious coexistence in the BR.
Profile

Protected area

Wienerwald BR

Mountain range

Alps

Country

Austria

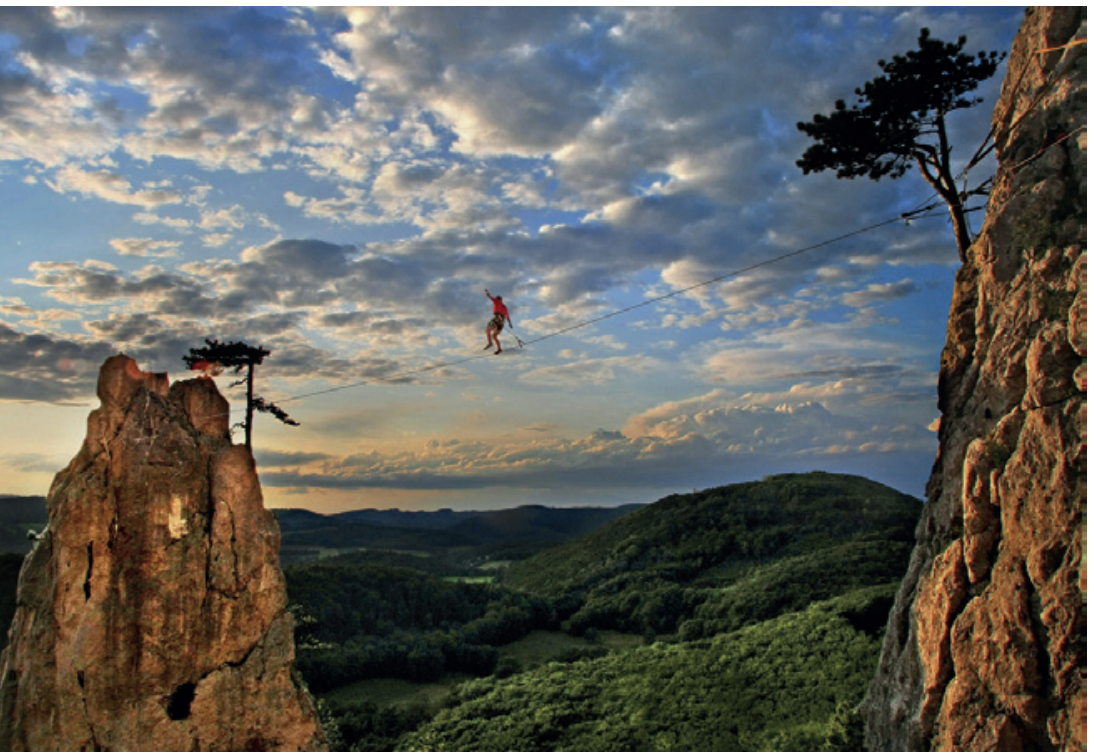

Figure 1 - Walking on an 85 metre-long slackline at the Peilstein. From the book "111 x Biosphärenpark Wienerwald". (C) Edition Lammerbuber

\section{Introduction}

The Wienerwald area, the largest contiguous deciduous forest in Central Europe, was included in the world network of UNESCO Biosphere Reserves. Wienerwald BR is made up of 51 municipalities in Lower Austria and 7 municipal districts of Vienna. 750000 people live in the BR's total area of 105645 ha (Lange 2005; Köck et al. 2009). In addition there are around 50000 second homes within the BR. Characteristic for the BR is its great diversity of landscapes, essentially the result of land use and, in part, of different climates and geologic conditions. The Wienerwald meadows in particular, with their high species diversity, are internationally significant. The exceptional diversity of natural and cultural landscapes make Wienerwald BR very attractive as a recreational space for both inhabitants and visitors.

Its special situation, the proximity to the large city of Vienna, brings with it some problems: nowhere else in Central Europe is a protected area exposed to such pressure and dynamics from an urban area (e.g. suburbanization, fragmentation of habitats, recreational use) as in the Wienerwald region (Reimoser et al. 2008). Two railway lines and two motorways cross the area or come close to it. Add to this the highly developed public transport network of Vienna and you have an easily accessible area.

The Wienerwald is a popular local recreation area for many people. Activities range from walking to cycling, jogging, mountain biking, horse-riding, hunting, climbing, cross-country skiing to geocaching. Unfortunately only rough estimates are available on the number of people frequenting Wienerwald BR for recreational purposes. More precise numbers exist for some parts only. For the Ottakringer Wald woodland alone, which covers an area of 192 ha, 0.4 million visitors per year have been recorded (Arnberger \& Eder 2007). The Lainzer Tiergarten area, also part of the $\mathrm{BR}$, is said to attract around 500000 visitors per year (Forstamt der Stadt Wien 2012). On the very conservative assumption that every inhabitant of Vienna visits the BR just once a year we arrive at nearly 2 million 
visitors per year. A study carried out in 1999 by the University of Natural Resources and Life Sciences in Vienna, estimates around 21 million visits per year by the population of Vienna alone (Bürg et al. 1999).

Inevitably in a protected area with such different and heavy uses, conflicts arise between individual user groups as well as with land owners and the BR management. One of the reasons is the size of the area and the large number of inhabitants and visitors who need to be informed about the three BR zones and the related regulations for their use (both options and restrictions). In Wienerwald BR, which was established in a top-down approach, such an information process takes a long time. Even now, ten years after it was created, many people are still not aware that they live in a BR or use it as visitors (Köck et al. 2013). This may explain why someone gathering mushrooms will react crossly when instructed by a ranger about restrictions in the core zone.

In general, however, the various requirements of different actors within the BR are quite compatible. Successful coexistence of different user groups can only work if there is mutual regard, for instance, expressed in compliance with certain rules of behaviour. The BR management, jointly with key actors, has created rules and suggestions for appropriate behaviour in the three zones of the BR. The project Spielregeln im Wienerwald: Richtiges Verbalten in den Wäldern des Biosphärenparks Wienerwald (Rules of Play in the Vienna Woods: Appropriate Behaviour in the Woodlands of Wienerwald BR) summarized these rules and suggestions for different user groups in a booklet.

\section{A participatory process}

First a working group was set up which included representatives of the BR management and land owners. It identified various groups of woodland users in Wienerwald BR and grouped them thematically. This rough draft formed the basis for a workshop with representatives of municipalities, forest owners, authorities, interest groups such as the Austrian Alpine Club and the Naturfreunde Association, and scientists of the University of Natural Resources and Life Sciences in Vienna. Unfortunately the heterogeneous group of the mountain bikers had no official representative in the BR when the project started so that no person could be identified who would be accepted as speaking for all mountain bikers. As all previous agreements on mountain biking in the Wienerwald area had been concluded between Wienerwald Tourismus and land owners, Wienerwald Tourismus was invited to the workshop as joint representative for tourism and mountain bikers. All actors seemed to agree on the pressing need for a meeting as evidenced by the fact that all followed the invitation of the BR management and participated in the workshop. It aimed at sharing information and current concerns, working on the user groups identified in the draft, clarifying the regulatory basis and getting

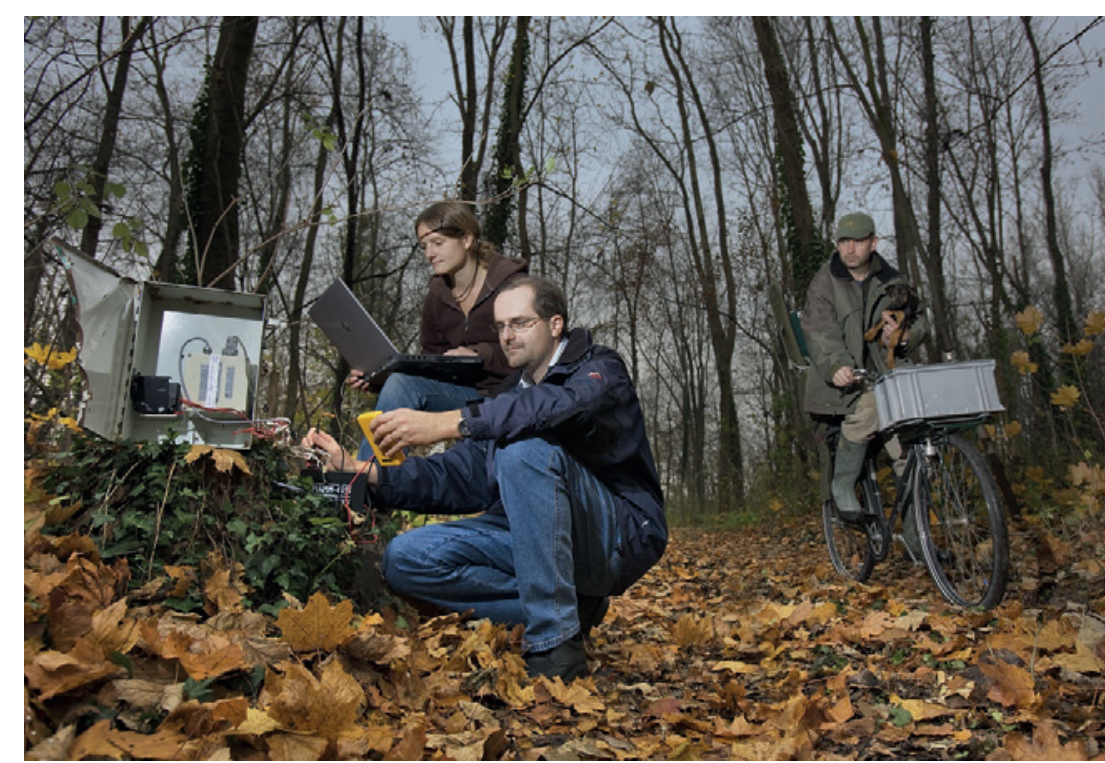

Figure 2 - Visitor countings are carried out by using photoelectric barriers. From the book „Planet Austria“. (C) Edition Lammerbuber

all participants to agree rules of play in the woodland. Special emphasis was put on the specific requirements of a BR (three zones with different conditions) and on the diverging framework conditions in the two federal provinces involved, i. e. Lower Austria and Vienna. The inputs gained in the workshop were integrated in the draft and the resulting document was sent out to all participants for feedback. All participants who agreed to the points of the document were also to provide their logos. Meanwhile additional major stakeholders had been identified and received the draft document: the National Scout Center Wassergspreng of the Austrian Boy Scouts and Girl Guides, the hunters, represented by the National Centre of the Austrian Associations for Hunting and Conservation, as well as equestrians, represented by the association Reitregion Wienerwald. Once the comments, criticisms and suggestions had been integrated, the manuscript for publication was submitted to the conservation and forestry authority of Lower Austria and to the BR coordinator of the city of Vienna for a check-up of the legal framework.

\section{Informative booklet}

The 39-page booklet presents the substance and aims of the BR, explains the three BR zones (core zone, buffer zone, development zone) in easily comprehensible form and lists the respective restrictions, requirements and usage options as well as the underlying regulatory framework. The booklet is being distributed by the actors involved and by BR partner organizations in education as well as through the partner network. It is also available at various mountain huts, popular walking destinations and at the information stations, can be downloaded for free from the Wienerwald BR homepage (http://www. 
bpww.at/fileadmin/Redakteure/Folder/Spielregeln_ im_Wienerwald_FINAL.pdf) and is available to the general public on request. The first edition of 15000 copies has already been almost completely taken up, a clear sign of positive reception.

Experience has shown that the booklet not only provides general information for the public but can also be used as a helpful instrument of de-escalation in certain cases. At so-called Core Zone Action Days, the BR management and BR partners inform people in situ about the BR, its zoning and appropriate behaviour. Conversation with various users often becomes very emotional. If you meet mountain bikers on an illegal track, it can be very difficult to reason with them. Most mountain bikers, even if they are not prepared to listen to arguments on the spot, do however take up the booklet and the information provided therein. No proper research on the effect has been carried out to date, but rangers have repeatedly met people in the woodlands who knew the booklet and were able to refer to individual points in it.

\section{Sample cases}

Let us look at some particularly contentious points. The Wienerwald BR core zones, strictly protected woodlands, obviously present the greatest potential for conflict. A considerable number of visitors baulk at the ban on collecting mushrooms, berries or herbs in the core zone. In this zone the absence of human intervention should maintain near virgin habitats for rare animals and plants and facilitate the emergence of virgin forests. In the 37 core zones, forestry was stopped in 2003. The only exceptions of this ban on any use are safety measures for the visitors (e.g. taking out old rotten trees along official marked walking, cycling or bridle paths) and protection measures for adjoining woodlands (e.g. taking out trees infested with bark beetle). As a rule the trees felled under these measures are left as dead wood in the forest and provide a habitat for many creatures. Many visitors find this unattractive and do not like the fact that much more dead wood is lying around in the core zone than before. Conflicts here arise when some visitors complain to the rangers, the $\mathrm{BR}$ management or even to the $\mathrm{MAB}$ National Committee about such apparently illegal logging, which is allowed in certain strictly defined situations. The booklet explains the background for such measures and points out that the increased amount of dead wood is not a sign of bad forestry but is left in the woodland on purpose and enhances species protection and species diversity as a precondition for a future virgin forest to develop.

Mountain biking is a particularly conflict-prone activity. This sport has evolved from a trendy pioneer sport to a leisure activity practised by an increasing number of people. While in a survey of 1987 just 4\% of interviewees claimed to cycle in the Wienerwald area, by 1993 that rate had risen to $31 \%$ and by 1998 had climbed further to 45\% (Bürg et al. 1999; Reimoser et al. 2013). Cycling is permitted throughout the BR on officially marked tracks only, something that many cyclists resent. The problem stems from the fact that the network of cycle tracks in Wienerwald, which extends over 1000 kilometres and $20000 \mathrm{~m}$ altitudinal difference, was created at a time when mountain bikes were much less technically sophisticated than they are today. The currently permitted tracks include large portions of sealed and forest roads, while today's bicycles are geared to much wilder terrain. Many mountain bikers therefore move on to smaller and steeper paths through the woodland where cycling is banned. Surveys on recreational use of Wienerwald $\mathrm{BR}$ with long-term video monitoring have shown that mountain biking is practised throughout the year, even in snow and that many cyclists ignore the ban on cycling off the permitted tracks (Arnberger \& Eder 2007; Reimoser et al. 2013). In the space of just one year, around 1800 mountain bikers were counted on a path where cycling is not permitted, (Arnberger \& Eder 2007). The booklet explains the ban on cycling on some tracks by pointing out the strain on wildlife by the fast and quiet approach by bicycle and the soil erosion caused by deep-tread tyres.

As with mountain biking, horse-riding in the BR is only permitted on marked bridle paths. In principle permission of the land owner has to be sought. Actual practice takes various forms, from individuals purchasing riding tickets to agreements between stable owners and land owners. The booklet explains how horse-riding and soil erosion through trampling disturbs wildlife, and provides a set of rules to avoid conflict under the title Reiter Fairplay.

The most frequent potential for conflict comes from dogs taken along into the BR. Vienna alone has currently 62000 registered dogs (up 16\% from the year 2010; Magistrat der Stadt Wien 2014), estimates of actual figures are twice that number. Naturally most dogs are found in suburban households and many dog owners walk their canines in nearby recreation areas. Inevitably this brings them in conflict with the interests of walkers, people pursuing all kinds of sports, land owners, hunters, farmers and conservationists. Many studies confirm that dog owners have a very low awareness of disturbance to wildlife (Sterl et al. 2008; Reimoser et al. 2013). Dog owners rate any disturbance caused by dogs as much smaller than how people moving through the BR without a dog assess it. The mere presence of a dog can trigger a wide range of reactions in wildlife as dogs are part of their enemy spectrum (Reimoser et al. 2013). The booklet offers suggestions on how to avoid conflict. It explains why dogs off the leash represent an enormous stress factor for wildlife. It also points out that requiring the dog to be on a leash does not just benefit wildlife but also the dog as it may catch diseases from contact with carrion or wildlife.

The good behaviour booklet also included suggestions for responsible research and education activities in the BR. The UNESCO Man and the Biosphere 
(MAB) Programme defines research and education as fundamental tasks for biosphere reserves and Wienerwald BR, too, enables numerous research and educational activities. The Austrian MAB National Committee has even been funding detailed research into the conflicts between users of the BR, stakeholders and land owners for years (Köck \& Grabherr 2014). One such project studied the economic and ecologic sustainability of using woodland biomass in Wienerwald BR and developed guidelines for retaining dead wood and old wood as an important precondition for maintaining biodiversity in the Vienna Woods (Sauberer et al. 2007). Three other projects served to establish criteria and indicators for sustainable handling of wildlife and their habitats as well as measures for minimizing emerging conflicts of use. These criteria and indicators allow actors from agriculture and forestry, leisure and recreation, plus the hunters, to assess for themselves how sustainable their handling of the requirements of wildlife really is and to develop and implement feasible measures from such self-assessments (Reimoser et al. 2008, 2012, 2013). A current project explores the acceptance of Wienerwald BR in the region and the integration of the local population in the BR (Eder \& Arnberger 2015). As the rules-of-behaviour booklet explains, all research projects and educational activities must gain the approval of the land owners. Projects funded by the MAB National Committee also must obtain approval from the BR management.

To sum up, the folder is an example of best practice for a transparent reference booklet that conveys the substance and aims of Wienerwald BR in exemplary manner. It presents the required rules of behaviour for all actors in an easily understandable form and promotes successful coexistence of all user groups in the biosphere reserve.

\section{Additional participatory action}

The folder is by no means the only measure taken Wienerwald BR to ensure good relations between all interest groups (forest owners, forestry actors, hunters, mountain bikers). As early as 2008, a joint initiative of mountain bikers and land owners called Fair Play, initiated by the federal province of Lower Austria, the Austrian forest owners interest group Land \& Forst Betriebe Österreich, the Austrian federal forests company Österreichische Bundesforste AG, the National Centre of the Austrian Associations for Hunting and Conservation, and the Federal Equestrian Federation, developed rules for cycling on woodland tracks. It should serve to avoid friction in the cooperation of the user groups. Under the heading Woodland dialogue meetings were set up with equestrians in the same way (Reimoser et al. 2008). In 2006 the federal province of Lower Austria joined forces with the Lower-Austrian hunting association to set up the project RespekTIERE deine Grenzen (respect your and the animals' limits). It produced an attractive folder to draw attention to po-

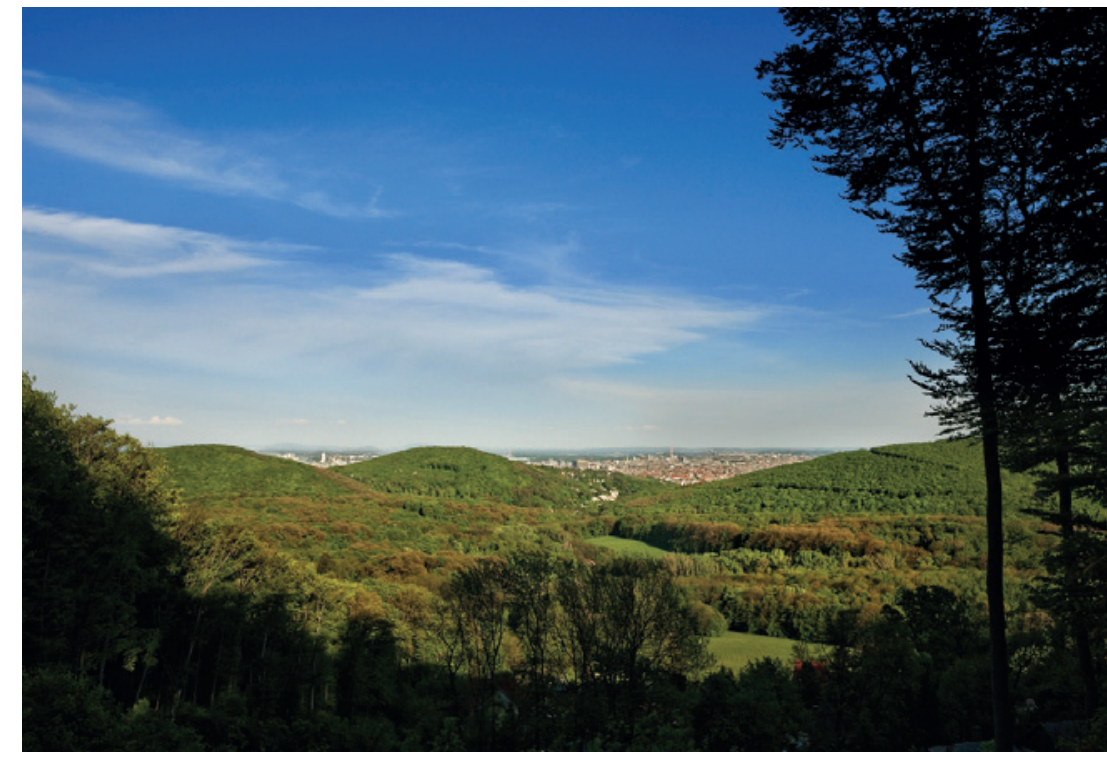

Figure 3 - The Vienna Woods are the largest contiguous area of deciduous woodland in Central Europe. It's location on the outskirts of a major city is unique. From the book "A Connoisseur's World - The Austrian Biosphere Reserves". (C) Edition Lammerbuber

tential problems between wildlife and people seeking recreation which includes an appeal to treat the environment with respect.

Currently a successful dialogue is under way between the BR management, the WienerWaldTrails association (created to organize mountain biking in Wienerwald BR and to establish an attractive legal track network), major land owners (Austrian Federal Forests, the forestry authority of Vienna, Stift Klosterneuburg) and Wienerwald Tourismus, in an effort to enable modern-style mountain biking in the BR and avoid conflict at the same time. Plans are afoot to create one attractive mountain bike trail to channel users and reduce the pressure on other woodland areas. The University of Natural Resources and Life Sciences in Vienna provides scientific advice throughout the process. In addition numerous guided tours and educational events serve to disseminate the rules of behaviour for each zone to the local population and to appeal to their cooperation.

\section{Acknowledgements}

We would like to thank Arne Arnberger and Christian Diry for their critical reading of the manuscript. We also wish to thank Brigitte Scott for the English language editing and Lois Lammerhuber for providing some of his fantastic photographs.

\section{References}

Arnberger, A \& R. Eder 2007. Monitoring recreational activities in urban forests using long-term video observation. Forestry 80 (1): 1-15. 
Arnberger, A., F. Frey-Roos, R. Eder, G. Muralt, U. Nopp-Mayr, H. Tomek \& M. Zohmann 2009. Ökologische und soziale Tragfähigkeiten als Managementherausforderungen für suburbane Biosphärenparke am Beispiel Untere Lobau. Report to the Austrian $M A B$ National Committee, Austrian Academy of Sciences, Vienna, 135 pp., doi: 10.1553/MAB-OEST, ISBN13 Online: 978-3-7001-6781-5. Available at: http:// epub.oeaw.ac.at/6781-5inhalt

Bürg, J., A. Ottitsch \& M. Pregernig 1999. Die Wiener und ihre Wälder: Zusammenfassend Analyse sozioökonomischer Erhebungen über die Beziehung der Wiener Stadtbevölkerung zu Wald und Walderholung. Schriftenreibe des Instituts für Sozioökonomike der Forst- und Holzwirtschaft, Band 37, Universität für Bodenkultur Wien.

Eder, R. \& A. Arnberger 2015. Biosphere People. Wie sieht die lokale Bevölkerung den Biosphärenpark Wienerwald? Report to the Austrian MAB National Committee, Austrian Academy of Sciences, Vienna.

Forstamt der Stadt Wien 2012. Statische Daten des Forstamts und Landwirtschaftsbetriebes der Stadt Wien (MA 49). Available at: https://www. wien.gv.at/umwelt/wald/forstamt/daten.html (accessed 28/01/2015)

Köck, G., G. Koch \& C. Diry 2009. The UNESCO Biosphere Reserve „Biosphärenpark Wienerwald“ (Vienna Woods) - a Long History of Conservation. eco.mont 1(1): 51-56.

Köck, G., M. Umhack \& C. Diry 2013. The Austrian Biosphere Reserves. A (connoisseur's) world beyond the cookery book. eco.mont 5(2): 59-63.

Köck, G. \& G. Grabherr 2014. 40 years of the UNESCO Man and the Biosphere Programme in Austriaa success story of ecologic basic research evolving into a flagship of transdisciplinarity. eco.mont 6(1): 57-62.

Lange, S. 2005. Inspired by diversity. Austrian Academy of Sciences Press, Vienna, Available at: http:/ / epub. oeaw.ac.at/3596-3inhalt

Magistrat der Stadt Wien 2014. Statistisches Jahrbuch der Stadt Wien 2014.

Reimoser, F., W. Lexer, C. Brandenburg, R. Zink, F. Heckl, A. Bartel, B. Ferner \& A. Muhar 2008. Integrated Sustainable Wildlife Management in the Biosphere Reserve Wienerwald. Report to the Austrian MAB National Committee, Austrian Academy of Sciences, Vienna. doi: 10.1553/ISWIMAB. Available at: http:/ / epub. oeaw.ac.at/6626-9inhalt

Reimoser, F., W. Lexer, C. Brandenburg, K. Ziener, B. Schreiber, A. Bartel, H. Tomek, F. Heckl, F. Hirn- schall \& A. Kasper 2012. IESP - Towards Integrated Ecological Spatial Planning for the Wienerwald Biosphere Reserve. Report to the Austrian MAB National Committee, Austrian Academy of Sciences, Vienna, 478 pp, doi:10.1553/IESP-Wienerwald, Available at: http://epub.oeaw.ac.at/7292-5inhalt

Reimoser, F., W. Lexer, C. Brandenburg, R. Zink, F. Heckl \& A. Bartel 2013. Integrative Sustainable Wildlife Management - Principles, Criteria and Indicators for Hunting, Forestry, Agriculture, Recreation. Report to the Austrian MAB National Committee, Austrian Academy of Sciences, Vienna. doi: 10.1553/ISWIMAN-2. Available at: http://epub.oeaw.ac.at/7216-1inhalt

Sauberer, N., E. Hochbichler, N. Milasowszky, B. Panagoitis \& L. Sachslehner 2007. Nachhaltiges Waldbiomassenmanagement im Biosphärenpark Wienerwald. Report to the Austrian MAB National Committee, Austrian Academy of Sciences, Vienna. doi: 10.1553/ wald. Available at: http://epub.oeaw.ac.at/3839-6inhalt

Sterl, P., C. Brandenburg \& A. Arnberger 2008. Visitors' awareness and assessment of recreational disturbance of wildlife in the Donau-Auen National Park. Journal for Nature Conservation 16: 135-145.

\section{Authors}

\section{Günter Köck}

is Secretary-General of the Austrian MAB National Committee, former Vice-Chair of the UNESCO MAB Programme, and the Austrian delegate to the European Alliance of Global Change Research Committees, member of the Scientific Board of Hohe Tauern National Park, as well as one of the Austrian delegates to the International Scientific Committee for Alpine Research. In 2009 he became co-editor of eco.mont.

\section{Harald Brenner}

joined Wienerwald BR management in 2010. The trained forest manager is responsible for the thematic areas of woodland, wildlife management, core zones and geographic information systems. His tasks include creating management plans for core zones, developing biodiversity monitoring systems as well as projects around social responsibility in the BR, such as developing the rules-of-behaviour booklet and participating in the working group on modernizing the mountain bike track network in the BR. 